\title{
English Major Undergraduates' Needs and Perceptions of Business English Activities and Resources in a Chinese University
}

\author{
Qing Xie \\ Jiangnan University, Wuxi, China
}

\begin{abstract}
This article explores English major undergraduates' views on business English skills and topics, and investigates their perceptions of the meaningful activities and resources in one Chinese university context. The main research instruments are questionnaires containing rating and open-ended questions, and researcher's participant observation with 149 English major undergraduates enrolling in Business English courses in 2016. The results show that participants most often require improvement in note-taking skills, public speaking and need to learn business communication topics. Participants value communicative teaching methodologies, including role plays, oral presentation, theme-based discussion, games and group work. Participants more often rely on electronic media resources, such as videos, internet and mobile applications than the print media resources such as library, books and dictionaries. This study serves as basis for further business English curriculum development and resources provision in the higher education setting. The study also indicates the potential for business English resources development and exploitation in China within the international education environment.
\end{abstract}

Index Terms - English major undergraduate, needs, perceptions, business English activities and resources, Chinese university

\section{INTRODUCTION}

Business English or English for business purposes is a major type of English for occupational purposes which is one of the two sub-branches under English for specific purposes (Dudley-Evans and St John, 1998, p.6). Business English can be further classified as "English for general business purposes" and "English for specific business purposes" (Dudley-Evans and St John, 1998, p.55). In the English for specific purposes research, understanding "learners' expectations" is an important area for academic study, which are varied among business professionals and university students (Dudley-Evans and St John, 1998, p.65). The focus of this study is to understand English major learners' expectations of English for general business purposes teaching activities and resources.

The development of business English teaching content requires authentic input as it links students closer to the real world of business. Frendo (2005, p. 52) summarizes that useful authentic content includes business communication documents, audio-visual materials such as "TV adverts and company sales videos" and internet. Ellis and Johnson (2002, p.162) also recommend recording "live events on audio or video" as sources of authentic learning content. According to Frendo (2005), various reading, writing, listening and discussion activities can be designed based on authentic materials to mirror the workplace interaction. The typical activities include "role play, simulation and case study" (p.54) to develop business English reading, writing, listening and speaking skills in meaningful settings. Donna (2000, p.126) mentions that business English courses should include "contextualized practice", which links with the authentic workplace settings. The development of business English activities should also consider whether students are able to complete the tasks. As Hutchinson and Waters (1987) summarize, the methodology design should follow second language learning principles. Moreover, Mishan (2013, p. 287) indicates that technological innovation transforms delivery modes. The evolution ranges from the traditional "teacher talk", to "blended learning, online chatting, mobile based language learning, to self-access computer assisted learning". There is no doubt that the technological advancement also transforms business English activities and resources, making their access easier and the content more diverse for learners.

In light of the trend, this study aims to explore the changes of learners' needs and perceptions of business English activities and resources under technological reforms. The investigation focuses on English major undergraduates in the Chinese university context, who are learning English language and literature as their academic development priority.

\section{RESEARCH QUESTIONS}

This study aims to investigate English major undergraduates' preferences of business English topics and skills for improvement, and their perceptions of activities and resources in the Chinese university context. It centers on the following three main research questions: 
1. What are English major undergraduates' needs of business English skills and topics in the Chinese university context?

2. What are English major undergraduates' perceptions of business English activities in the Chinese university context?

3. How do English major undergraduates locate and use business English resources in the Chinese university context?

\section{REVIEW OF LITERATURE}

\section{A. Understanding Business English Activities and Resources in the International Context}

According to Emmerson and Hamilton (2005, p.1), business English activities can integrate speaking and writing tasks. They are designed to focus on particular business or communication topics. They could be designed to "review vocabulary", "lead-in" discussion or round-off the class. The length of the business English activities varies, depending on the functions in the curriculum.

Studies on business English activities and resources can be found in various contexts. In the study of Pratoomrat and Rajprasit (2014) on business English instruction in the Thai university context, students and teachers' perceptions of business English instruction are investigated using syllabus analysis and questionnaires. The results show that participants are positive towards the business English instruction. However, there is inconsistency between the needs and the curriculum content. It is suggested that a needs analysis should be conducted to bridge the gap between the business English courses and professional needs. In another context, Edwards' study (2000, p.293) on a business English training for German bankers has chosen "deductive presentations" and "communicative" language exercises based on authentic texts from the business magazines and video records drawn from the workplaces.

Moreover, in the English for specific purposes context, Dudley-Evans and St John (1998, p. 204) have mentioned that the use of technology in learning beyond classroom enriches the English language teaching content and provides more resources and opportunities in enhancing learning outcomes. The technology advancement consists of "multimedia resources, the internet, electronic mails, CALL (Computer Assisted Language Learning) materials and computer-based corpora". Robinson (1991, p. 62) mentions that the teaching resources can consist of "visual and mechanical aids, videos and computers". In the recent literature, the use of corpora in teaching has been a growing trend (Flowerdew, 2011).

Through three years of experiences in designing and implementing English for Specific Purposes program for mixed level students, Yogman and Kaylani (1996, p. 321) summarize that mini-projects, technology such as video, ESL situation such as communicating with native speakers and a portfolio approach should be adopted. In view of the lack of correct understanding about computer assisted language learning in business English teaching, Vallance (1998) has developed the internet resource of Business Meeting and gathered feedback from learners worldwide. The internet resources prove useful and receive positive comments from both learners and English Language Teaching (ELT) professionals. Effective individualized learning can be achieved. It can be summarized that in the current trend of business English teaching, various technological innovations have been well incorporated into the curricula and the technological resources should be exploited.

\section{B. Business English Activities and Resources in the Chinese Context}

In the Chinese context, Lu (2015) indicates that multimedia technology can be better used to collect teaching materials for both teacher and students. It can optimize teacher-student interaction and nurture student creativity and independence. Liu (2015) further elaborates that the use of internet learning resources should be fully utilized in business English teaching. It can bring the real business situation to the classroom and diversify teaching models. Teacher should introduce learning resources to students and establish instant communication and self-access learning platforms. In view of the weaknesses in business English teaching practice in China, Hu (2015) summarizes that using internet resources can enhance learners' listening, speaking and writing skills development. Moreover, in the context of Hong Kong, China for business English teaching, Evans' study (2012) intends to bridge the gap between the classroom and the workplace by designing email tasks based on the qualitative interview data, case studies and email samples collected from the workplaces which have strong pedagogical implications.

Moreover, there is a recent trend that the newly developed Chinese teaching theory on the production-oriented teaching approach (Wen, 2016) has been introduced into the business English courses. According to Wen (2016, p.4), the production-oriented approach is "learning centered" and has a focus on "holistic development". It integrates learning and teaching and follows the process of "motivating, enabling and evaluating". It mainly focuses on the development of output skills such as speaking, writing and translating, based on the comprehensible input of reading and listening materials. Sun (2017) has applied this production oriented approach in teaching business English vocabulary in the university context, based on corpus data and cognitive theories.

In the context of business English course design, Cao (2015) mentions that in order to create a proactive learning environment, rich teaching resources should be provided. It may consist of multi-media lab, internet-based self-access learning center, wireless radio and a range of co-curricular activities such as English speech competition, English singing competition and other communicative events. An (2008) mentions that internet resources can enrich the 
teaching materials. Software can be downloaded for language learning. Students can visit interesting language learning websites and browse the e-library. Using e-learning tools can enhance students' speaking and writing skills. In the Chinese context, it is also seen that various technological reforms and authentic resources have been integrated into business English teaching.

\section{Investigating Learner Perceptions of English Language Activities and Resources for Various Contexts}

As well documented in literature, McGrath (2013, p. 158) summarizes that English language teaching resources can also be based on coursebooks and authentic materials. The sources of teaching resources can include "TV, magazine, advertisement and popular music". Internet can also provide additional materials for English language teaching. In addition, students may have different preferences of the teaching activities, such as "small group work, pair work, discussion and role play". However it is indicated that results of the studies may vary as they may be context and student specific. Previous studies explore from different angles learner perceptions of English language activities and resources for various contexts.

In Barcelona, Spain, Block (1994) differentiates teacher's and learners' perceptions of activities in an English as a foreign language class. The teacher and learners differ in viewing the purposes of the activities. It is suggested that teacher orients the activities more in line with learners' preferences. Based on the conception of learner-centered curriculum, Barkhuizen (1998) investigates about 60 South African high school students' perceptions of 15 English learning activities using a multi-method approach, combining questionnaire, composition, observation and interviews. The results show that teacher and students' perceptions do not match.

In the Chinese university context, Wei (2004) investigates 192 English major undergraduates' perceptions of 20 oral English teaching activities regarding their effectiveness in improving oral communicative competence and whether students consider them as interesting methods. Teacher guided practice is considered more effective while free talk and practice is seen as more interesting. Simulated practices using drills are considered the least effective and interesting.

In Open University of Hong Kong, Zhang, Perris and Yeung (2005) explore students' perceptions of the use of technology and internet in course learning, as well as the online tutorial support. The study concludes that while students have positive perceptions of the use of internet and technology, the focus should be shifted from the issue of access towards "language and interaction" (p. 803). Jackson (2003) explores case-based teaching in the Chinese university of Hong Kong by investigating the views of twenty business professors and 589 students by questionnaires and follow-up interviews. The study reveals that while business professors generally consider Asian students as reticent, the students raise the inadequacy of English language preparation for case-based discussion as the constraint factor. It is suggested that group work should be used to facilitate the sharing of ideas in class.

However, it can be found that previous studies on learner perceptions of English language resources and activities have not been focused on business English teaching for English major undergraduates. Previous studies did not compare and contrast the usefulness of various business English teaching activities, as well as traditional and technological resources, based on students' perceptions.

\section{Methodology}

Investigating learner needs of business English skills and topics and exploring their perceptions of activities and resources require both quantitative and qualitative methodologies (Brown, 2014). It is considered that the combination of quantitative and qualitative approaches would provide a more comprehensive understanding of the issue under study (Creswell, 2014). The data collection, participant information and data analysis procedures are thus explained in the following sections.

\section{A. Data Collection}

The study mainly adopts paper-based questionnaires as the data collection instruments. The questionnaires containing 13 rating and open-ended questions were administered in September 2016 in the first week of the course Business English to English major undergraduates in a Chinese university. The course focuses on business English communication skills at intermediate level. The course has 32 teaching hours within a 4-month period. The content of the course is mainly based on the coursebooks Further Ahead: A Communication Skills Course for Business English (Jones-Macziola \& White, 2003) and Chinese Companies versus Foreign Companies: A Practical Business English Reader (Yang, 2012). The 13 questions in the questionnaire are designed based on the instruments developed by Hedge (2002, p. 344), Basturkmen (2010, p. 30) and Harding (2007, p. 20). It aims to gather participant views on business English skills and topics for improvement, perceptions of business English activities and resources from different angles. The data collection process follows the ethical principles of second language research (Dörnyei and Taguchi, 2011, p.80). Participants consent was obtained prior to the data collection process. The confidentiality of the participant and organization identity has been protected and pseudonym is used for this study.

Moreover, researcher also delivered the course and conducted participant observation for the business English learning process to triangulate the findings from paper-based questionnaires with insider perspectives.

\section{B. Participants}


This study chooses one Chinese university with a School of Foreign Studies which hosts a four-year bachelor program of English language and literature, consisting of different modules, such as English foundation, translation and interpretation, literature and business English. The modules are being upgraded regularly, with the aims to train language professionals with diverse competence including professional communication skills.

149 English major undergraduates in their second year of the English program in the Chinese university were valid participants of the study. All of them enrolled in an elective Business English in September 2016. Twenty-two participants were male and 127 were female. Their age range was 18 22 years old. The average age was 19.4 years old. Less than half of the participants had passed College English Test (CET)-Band 4. There were four advanced learners who took International English Language Test System (IELTS) examination and one even obtained a high score of 8.

In order to know participants' prior business English learning experiences, participants self-assessed their business English levels. Beginner level takes up the largest group of $68.46 \%$ of the participants. The rest of the participants are almost equally spread in higher beginner, intermediate and low intermediate levels.

In order to understand participants' strengths and weaknesses in specific English communication skills, participants also examined their own language abilities in listening, speaking, reading and writing, which are described through a 1 4 rating scale, with 4 being the highest level of language ability. It was found that reading had the highest mean of 2.62 while speaking was the lowest at 2.12. Listening and writing were in the medium at around 2.2. It indicates that speaking should be the priority area for further improvement.

For motivation of learning English, $62.42 \%$ of the participants claimed medium level motivation while $31.54 \%$ of the participants held high level motivation. There were only a few participants who had low level motivation.

For reasons to study business English, 31.54\% of the participants linked business English learning to finding job or career preparation. There were $14.09 \%$ of the participants who had clear objectives of working for international organization or foreign company, such as "German company". 12.75\% of the participants had more general purposes such as to learn knowledge, broaden horizon and improve ability. They may also hope to develop professional communication skills. 8.05\% of the participants considered business English as useful or they were interested in the subject. A few participants hoped to know cultures of different countries. There were also practical learners who hope to pass Business English Certificate (BEC) tests.

\section{Data Analysis}

The participants' needs of the business English topics and skills are measured by the frequency of the main themes in the responses and their percentages of the participants as learners of English language and literature as their major academic study area. The participants' learning needs are also measured by means of a range of 1 4 regarding how often they do the different types of writing in their study. The frequency and percentage of participants' perceptions of activities and resources are also calculated. The differences of needs and perceptions of male and female participants, as well as advanced and average learners are compared and shown in the following graphs, which add more substance to the results. Theories of individual differences in second language learners have also revealed that gender and language aptitude are two of the differentiating factors (Hou, 2008), which this study is focusing on. For qualitative information, major themes are analyzed and best quotes (Guest, MacQueen \& Namey, 2012) drawn from participants' responses to open-ended questions. The insights gained by the researcher through participant observation supplement the results from paper-based questionnaires.

\section{RESULTS}

\section{A. Participants'Needs of Business English Skills and Topics in the Chinese University Context}

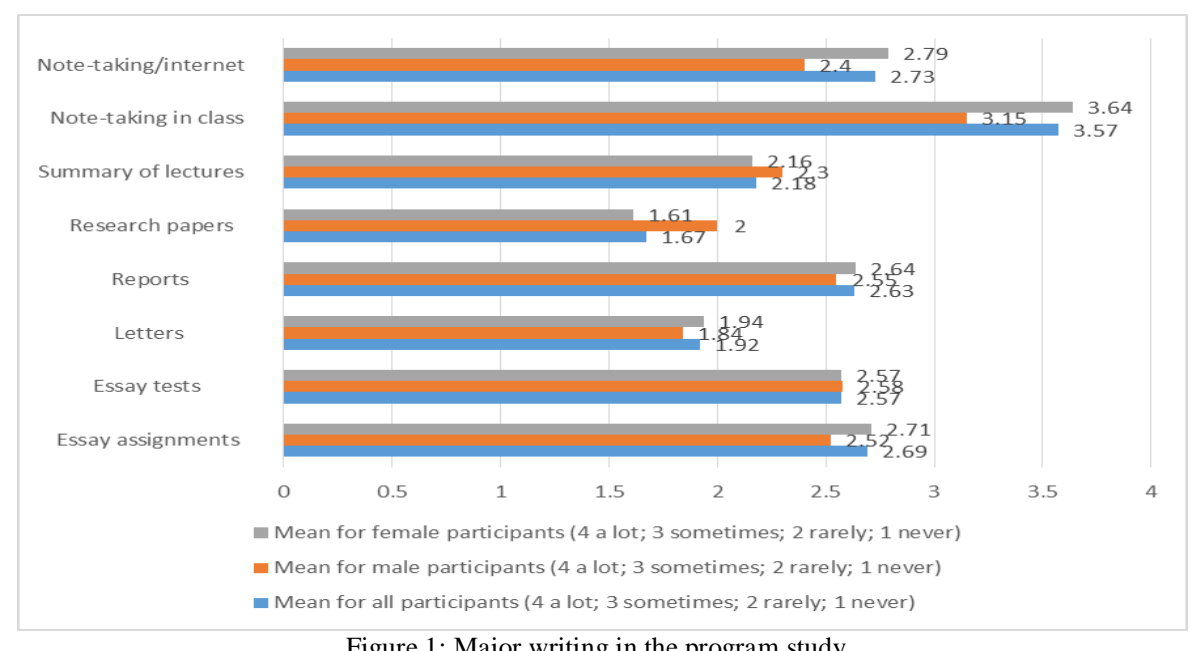

Figure 1: Major writing in the program study 
Participants' major writing tasks in the program study are summarized in Figure 1, in a range of 1 4, with 4 meaning a lot while 1 indicating never. The analysis shows that note-taking in class has the highest mean of 3.57, with male participants at 3.15 and female participants at 3.64, which clearly indicates note-taking as an important learning skill for these English major learners. Essay assignments, essay tests, reports and note-taking/internet have means for all participants at over 2.5, which are occasional writing activities conducted by the participants. Summary of lectures, letters and research papers become less frequent writing tasks for participants. Male participants have lower means in all types of writing than female participants, except in the item of research papers, which has higher mean than their female counterparts. For advanced learners, essay assignment has the highest mean of 3.5, while research papers and summary of lectures have the lowest mean of 1.5 , same as the other participants.

The business English skills, categorized as specific speaking, reading, writing and speaking tasks, participants would like to improve in their study are summarized in Figure 2. For speaking, over $75 \%$ of the participants hoped to improve public speaking, with over $77 \%$ of male participants and over $74 \%$ of female participants. Staying on a topic and persuasive questioning take up around $30 \%$ of the participants, with over $13 \%$ male participants and more than $37 \%$ female participants. Public speaking can be a priority area for business English teaching.

For reading, over $60 \%$ of all participants needed to improve quick reading skills and understand articles, journals, abstracts and trade publication. Over $35 \%$ of all participants needed to improve skills for reading reports and over $22 \%$ of all participants also hoped to learn to read correspondence. For reading skills, the priority should be given to quick reading, articles, journals, abstracts and trade publication.

For writing, more than $50 \%$ of all participants needed to improve writing reports, business letters, and applications, proposals and invoices, which should be the focus of business English curriculum. Over $49 \%$ of all participants hoped to improve note-taking on talks. Around 33\% of all participants hoped to improve writing skills for emails, cover letters and CVs. Memo writing takes up around $25 \%$ of the participants.

For listening, over $74 \%$ of all participants listened to radio, TV and internet broadcasts with over $68 \%$ of male participants and more than $75 \%$ of female participants, which seems to be the main source of audio input. Over $60 \%$ of all participants also needed to listen to natural speech. Over one third of all participants also indicated the need to improve listening skills for the main idea/key points and to people from non-English speaking countries.

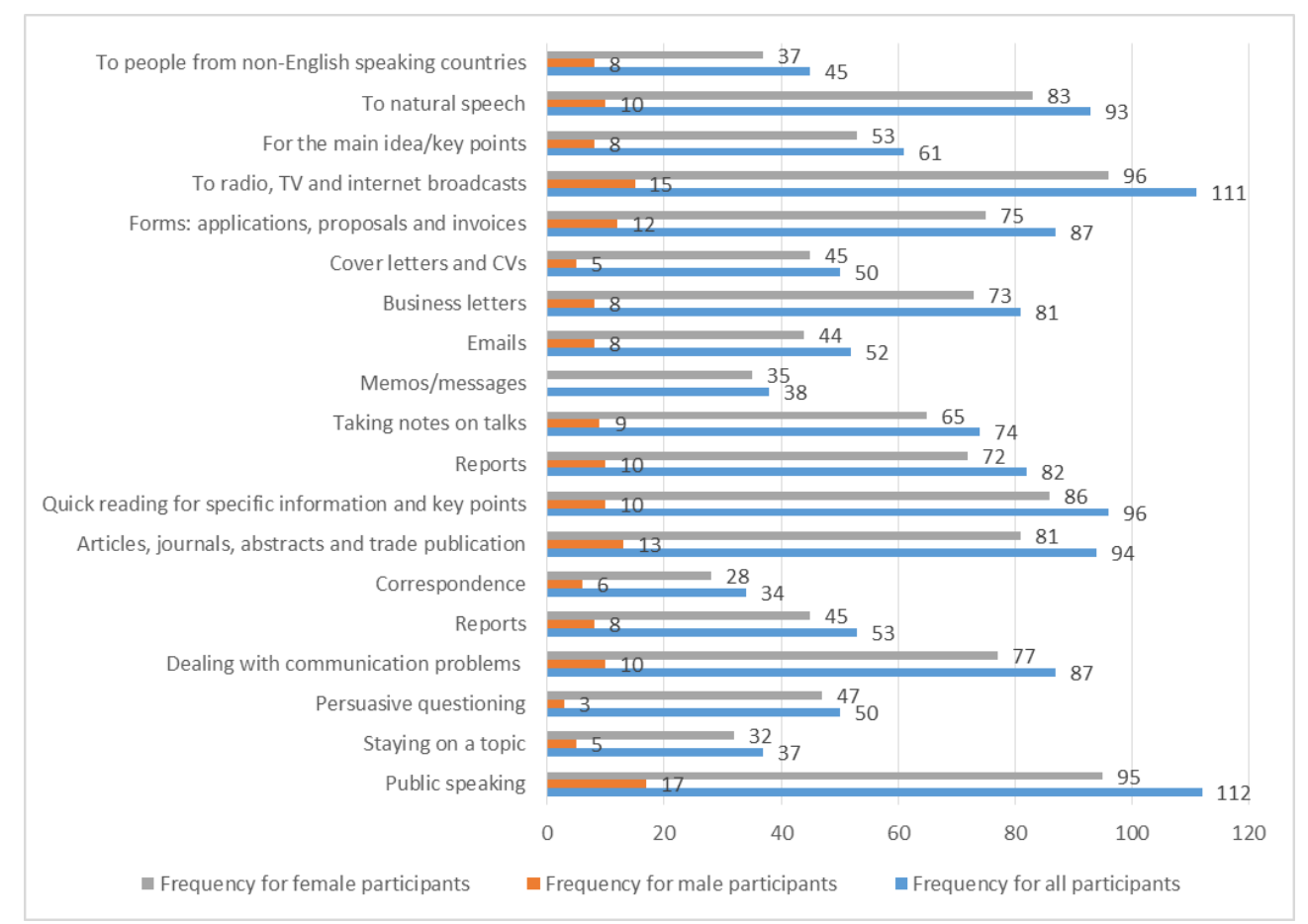

Figure 2: The business English skills to improve

Participants' views for the business English topics to learn are summarized in Figure 3. Around $30 \%$ of all participants mentioned business communication as the key topic for learning, with over $31 \%$ of male participants and over $29 \%$ of female participants. These could vary from business report, email, CVs, business etiquette to attending job interview. The following two participants have demonstrated how they should be trained for business communication skills with a pragmatic focus.

I wish to learn how to act well when I was interviewed in a big company, how to leave a deep impression to others. (Participant A)

I'm quite curious about the business etiquette which would help me to behave myself at the proper 
time. (Participant B)

More than $10 \%$ of all participants mentioned world trade and finance and marketing including advertising. Banking is a frequent word. Around $6 \%$ of all participants hoped to learn about negotiation. These are mostly mentioned by female participants. Participant $\mathrm{C}$ had the following explanation.

I wish I can learn negotiation and how should we prepare if we want to hunt for a job in a foreign company. (Participant C)

Over $3 \%$ of all participants raised business vocabulary such as business English wordlist and usage as important topics. Around $2 \%$ of all participants also mentioned the topics of corporate history, Chinese businesses, cross-cultural communication including politics, jobs and statistics as they preferred. These are again all female participants. For example, participant $\mathrm{D}$ had the following elaboration.

I am interested particularly in China's business development, with companies such as the growth of

JD.com, Huawei and Wanda etc. (Participant D)

For the advanced learners in the group, their needs for business English topics range from drama to business practice needs. Participant E mentioned "how to dress well in formal occasions/how to interpret some professional words". Other advanced learners also mentioned the needs to learn business subject knowledge such as marketing and to prepare for BEC test, which are similar to the other participants.

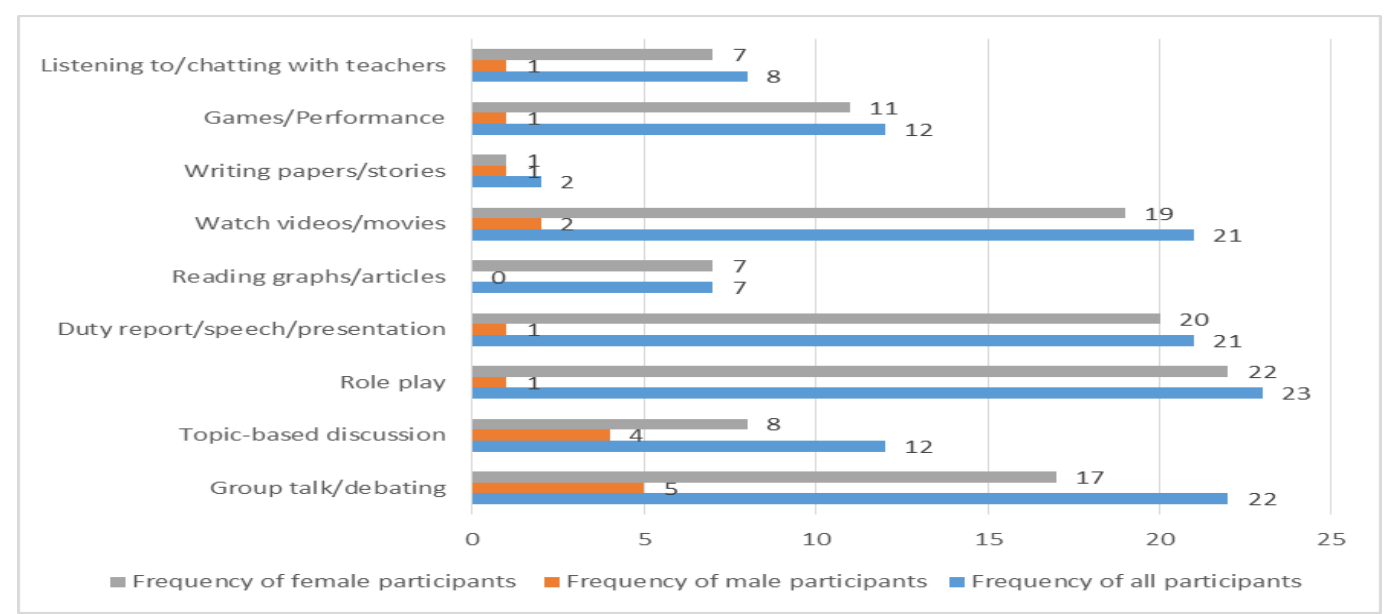

Figure 3: Business English topics to learn

\section{B. Participants' Perceptions of Business English Activities in the Chinese University Context}

Participants' favorite activities in English classes are summarized in Figure 4. Over 15\% of all participants considered role play as meaningful activities with over $4 \%$ of male participants and over $17 \%$ of female participants. Over $14 \%$ of all participants also mentioned group work/debating, oral presentation, and watching videos/movies as useful learning activities. Participants F, G had the following elaboration.

I like group work. Many students sit together and then discuss about the topic. (Participant F)

When teachers show us films and play music, I feel more relaxed and focus more on English study. (Participant G)

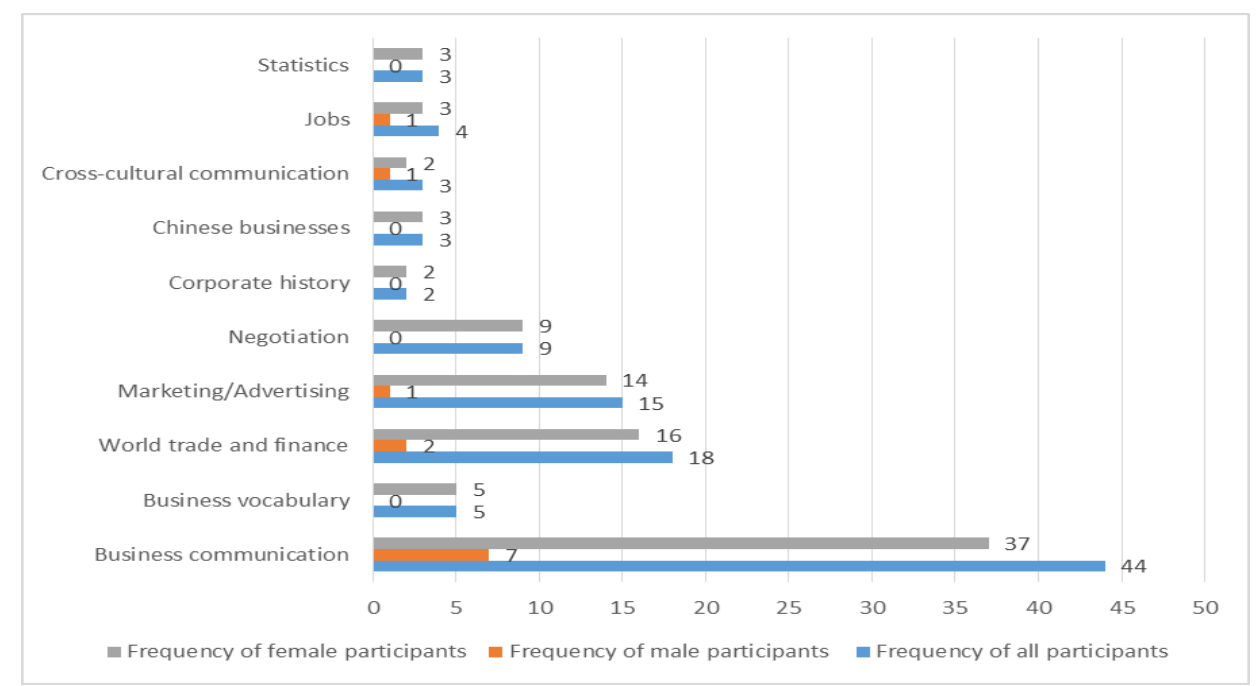

Figure 4: Favorite activities in English classes 
Over $8 \%$ of all participants also preferred topic-based discussion and games/performance, with over $18 \%$ of male participants and over $6 \%$ of female participants. Participant $\mathrm{H}$ described her personal experience.

Games! Actually, I love those activities which push us to think and talk. (Participant H)

Reading articles, writing papers and listening to teachers were also indicated by less than $6 \%$ of all participants as making important contributions to their language learning, who are mainly female participants.

For advanced learners, their favorite activities in English classes are the same as the other participants, which include presentation/public speaking, role play, teamwork and debating.

Participants' perceived most helpful business English activities are described in Figure 5. Around 20\% of all participants mentioned making speech/presentation as the helpful activity, with over 13\% male participants and over $20 \%$ female participants. Over $15 \%$ of all participants praised group talk/debate, with over $9 \%$ male participants and over $16 \%$ female participants. For example, participant I had the following explanation about the benefits of team event.

Team event. It usually concludes discussion, division of work, statement of the group. It can really give more space to students and be more creative, active. (Participant I)

Over $14 \%$ of all participants favored team-based discussion, with over $13 \%$ male participants and over $14 \%$ female participants. Participant J described her view.

The teacher will give us a topic for us to discuss freely. The teacher will then let students to speak and state his or her view. It may be difficult for us to express clearly. But with guided classroom discussion, our thinking and speaking ability can be improved. (Translation, Participant J)

Less than $10 \%$ of all participants also mentioned teacher-student interaction, role play, listening, doing exercises, reading, dictation, teacher talk and communicating with foreigners as useful pathways, mostly female participants. Participant K even raised "watching and experiencing the real situation" as an important route for improving business communication skills. For advanced learners, three out of four mentioned that English speech and communicative activities are helpful, which is the same as the other participants.

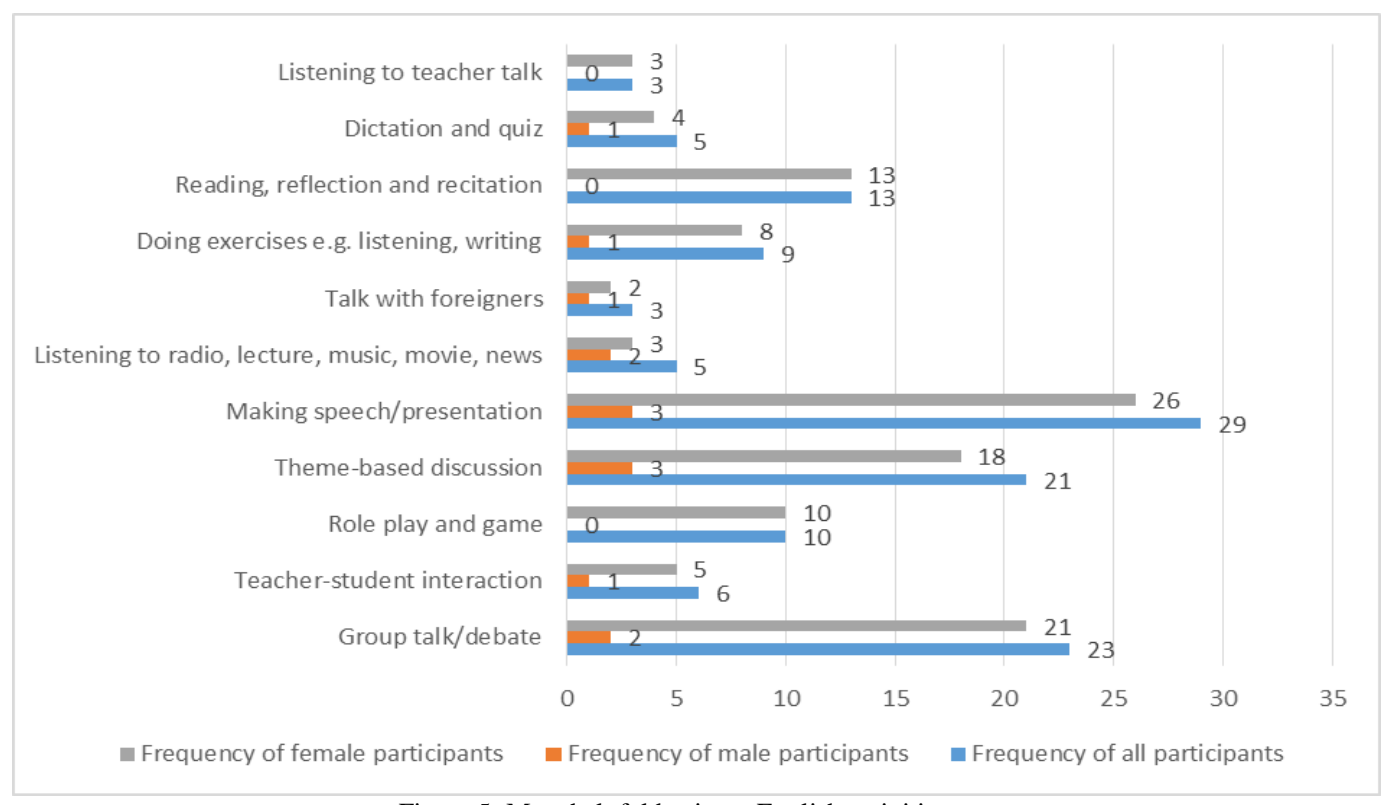

Figure 5: Most helpful business English activities

\section{Participants'Perceptions of Business English Resources in the Chinese University Context}

For learning business English outside class, participants have identified various routes, as shown in Figure 6. More than $48 \%$ of all participants indicated watching movies or TV shows, such as TED as their way of English learning, with over $40 \%$ male participants and over $50 \%$ female participants. Two out of four participants also used movies and videos as the resources for out-of-class learning. Participant L expressed her experience.

I tend to watch US TV series to get to know the customs and ideology. (Participant L)

Around $40 \%$ of all participants also mentioned listening and reading activities as useful routes for learning English, which include books, magazines and news. Two out of four advanced learners are the same as this group of participants. Participant $\mathrm{M}$ had the following explanation.

I prefer reading and reciting texts outside the room, which makes it easier and funnier to study.

(Participant M)

More than $13 \%$ of all participants also used mobile applications such as English learning software and Wechat as useful resources for their learning, with over $9 \%$ male participants and over $14 \%$ female participants. Participants $\mathrm{N}$, O described their experiences.

I have downloaded many Apps and followed many Wechat Subscription Accounts. (Participant N) 
Use some Apps to help me to remember new words and read some English passages. (Participant O)

Less than $10 \%$ of all participants relied on internet, dictionaries, talking with foreign friends, doing exercises, taking online classes and debating as sources of English learning. Two participants especially raised the importance of English speaking environment. Participant $\mathrm{P}$ had her observation.

I am a crazy lover about traveling. This past summer I went to Sri Lanka to be a volunteer teacher and traveled a lot for 6 weeks. So for me, being in an environment where everyone speaks English is the best way to learn English. (Participant P)

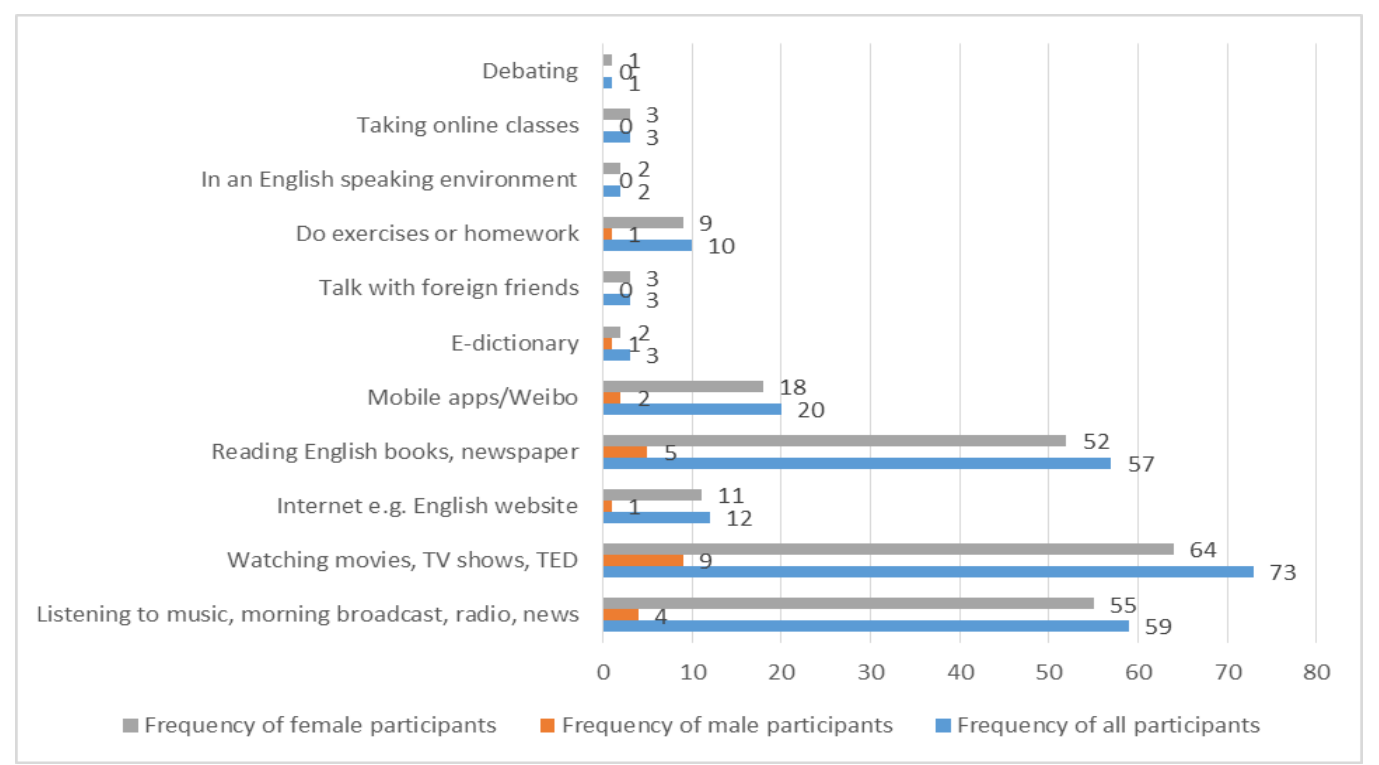

Figure 6: Participants' routes of learning business English outside class

How participants locate business English learning resources is described in Figure 7. The graph has shown that internet has become one of the major sources of business English learning resources. More than 57\% of all participants have used internet as their business English learning resources, with 50\% male participants and over 59\% female participants. Participants Q, R had their explanation.

Read internet expert's recommended posts and join in English learning group. (Participant Q)

I usually use English as a practical skill for communication. And I have to contact friends English, everyday through WhatsApp or emails. So maybe I usually use internet and read news every day. (Participant R)

More than $20 \%$ of all participants also relied on teacher or friend's introduction of learning resources, who are mostly female participants. More than $13 \%$ of all participants relied on mobile apps, who are all female participants. Over $10 \%$ of the participants searched books through university library, who are mostly female. Less than $10 \%$ of all participants also praised the usefulness of books, newspaper, magazine, dictionary, and multimedia resources such as online videos, BBC etc. as useful learning resources. The advanced learners are the same as the other participants.

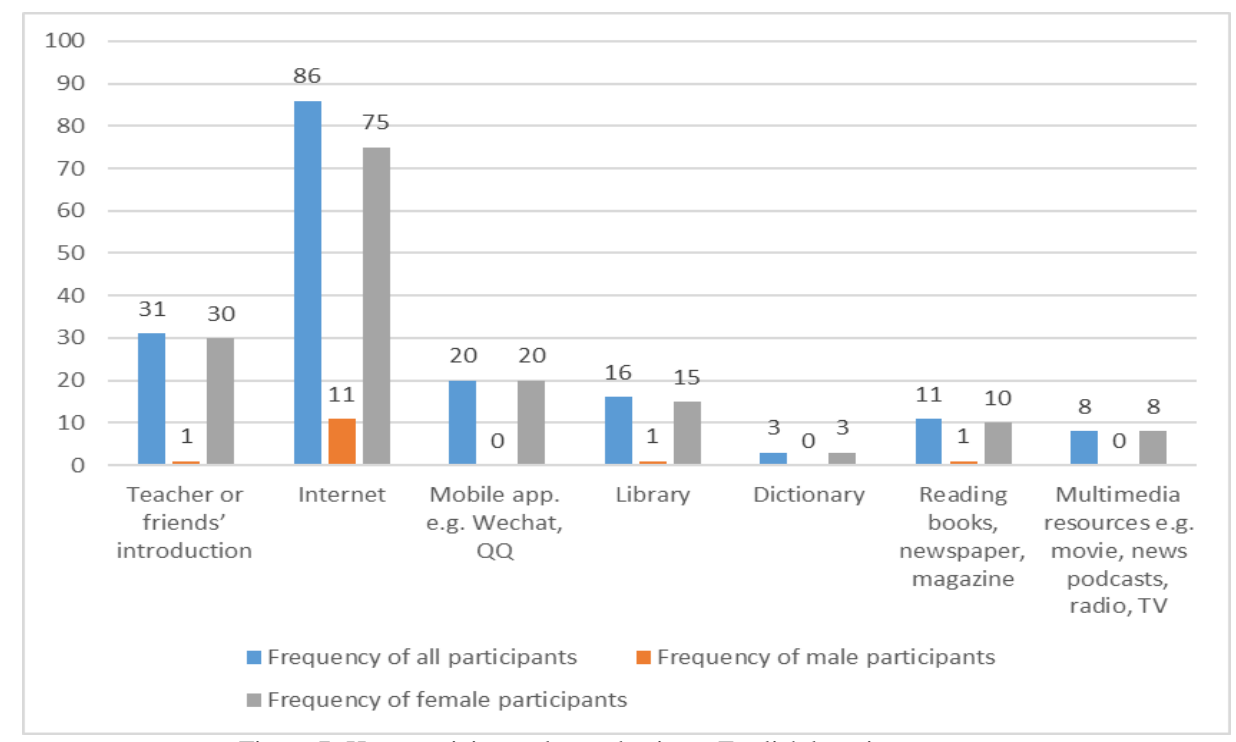

Figure 7: How participants locate business English learning resources 
By participant observation, the researcher also considers that the promotion of business English learning activities and resources available on campus is required. It is to ensure that the students realize the availability of the learning resources, such as the series of public lectures given by foreign teachers, the internet resources on the university websites including free lecture videos, and the various international communication activities among students from different countries.

\section{DISCUSSION}

\section{A. Participants'Needs of Business English Skills and Topics in the Chinese University Context}

The study shows that all participants most often require note-taking skills in their program study. For advanced learners, essay assignment is the most frequent writing type. Participants also often write essays, reports and note-taking/internet. But summary of lectures, letters and research papers are not the usual writing types often done by all the participants. For business communication skills, they most need to improve skills of public speaking, quick reading and the writing of reports, business letters, and applications, proposals and invoices. Participants need to listen to radio, TV and internet broadcasts. By comparison, it is very clear that public speaking and listening to multi-media recordings become the most important business communication skills in participants' perceptions. For business topics, participants hope to learn business communication related themes most. Other topics such as trade, finance and marketing etc. are also on the recommended list. For advanced learners, the preferred business topics are also specific, which are relevant to the real-world business practice and concrete business knowledge. These preferred business English skills and topics should be the focus of the curriculum development. They are covered in business English courses (Donna, 2000; Irigoin \& Tsai, 1995), and the content should also be connected to English majors' program study requirements.

\section{B. Participants'Perceptions of Business English Activities in the Chinese University Context}

For business English activities, all participants value role plays. They also mentioned group work such as debating, oral presentation, watching videos/movies as useful activities. They also like topic-based discussion, games and performance. Reading, writing and listening activities also are useful, especially for female participants. Participants consider making speech/presentation as most helpful activity. Teacher-student interaction, role play, listening, doing exercises, reading, dictation, teacher talk and communicating with foreigners are also mentioned as useful way of English learning, especially for female participants. Advanced learners are the same as the other participants. Most of these business English activities perceived by the participants as effective ones belong to communicative methodologies (Richards \& Rodgers, 1986; Brumfit \& Johnson, 2000). Similarly, for teaching and learning business English in the Spanish university context, Fuertes-Olivera and Go' mez-Martı'nez (2004) also find that the grammar translation methodology has negative influences on the learning outcomes and the norms of communicative methodology should be introduced to students. Moreover, Emmerson and Hamilton (2005) indicate that the design of business English teaching activities can integrate reading and listening texts with a communicative focus. Business English teachers are suggested to use multiple approaches in designing activities.

\section{Participants'Perceptions of Business English Resources in the Chinese University Context}

Participants mentioned watching movies or TV shows as their way of learning English outside class. They also rely on mobile applications to learn English. They occasionally rely on internet, dictionaries, talking with foreign friends, doing exercises, taking online classes and debating to learn English. Most of the participants rely on surfing internet to gain learning resources. They also occasionally rely on teacher and friends' introduction, university library, book, magazines, news, dictionary and multimedia resources for learning English. The advanced learners are the same as the other participants. The results show that these English major undergraduates no longer only rely on the traditional print media for learning resources such as book, dictionary and library. They largely acquire English through electronic media such as videos, mobile phone and internet. By comparison, it can be found that internet is the major source of English learning resources. This trend is discovered in ranges of studies on the use of microblog (Davies, 2015) and wiki platform (Wang, Zou, Wang \& Xing, 2013) in language learning. Participants realize the importance of language learning environment on improving business communicative competence. This is also recognized in the study of Trinder (2013) in the Austrian university context. Trinder (2013) indicates that being immersed in the English use environment and oral communication are two effective means of language learning. Successful learners have a higher level of autonomy and exploit learning resources more effectively.

\section{CONCLUSION}

This study investigates English major undergraduates' views on business English skills and topics, and investigates their perceptions of the meaningful activities and resources in one Chinese university context. It can be summarized that public speaking, listening to multimedia resources, and business communication themes should be the focus of further business English curriculum development. In general, female participants have stronger needs and expectations in various English learning activities than male participants. Advanced learners have very concrete requirements of 
business English topics relevant to business practice and knowledge. Moreover, communicative teaching methodology should be the focus of pedagogical innovation. This study offers unique insights into business English teaching and learning in a Chinese university. It implies that systematic guidance is especially required to lead students onto the right track of business English learning. The results of the study serve as basis for further business English curriculum development and resources provision in higher education environment.

The study finds that internet as well as movies and videos are perceived as the most important electronic sources of language learning resources. The study thus indicates the potential for business English resources development and exploitation. The publishers and material developers should recognize the importance of electronic media in addition to the print media. While learners have easier access to electronic media resources, the content developers should also be ready with more diverse, up-to-date and attractive materials.

The results of the study inform business English teaching and learning in the university context. Though the study offers results in only one university, the research process can be replicated in other cultural or educational settings. The business English teaching professionals should follow the current trends to better meet student learning needs. Future research should explore the possibility of incorporating technological innovation such as blended learning and online learning in business English curriculum. Future research should also focus on how to cultivate practical communication skills in business English programs.

\section{APPENDIX}

Adapted from Hedge (2002, p. 344), Basturkmen (2010, p. 30) and Harding (2007, p. 20)

\section{Needs Analysis}

1. Name_ Gender__________

2. How would you describe your Business English level?

\begin{tabular}{|l|l|l|l|l|l|l|}
\hline Beginner & $\begin{array}{l}\text { High } \\
\text { Beginner }\end{array}$ & Low Intermediate & Intermediate & $\begin{array}{l}\text { High } \\
\text { Intermediate }\end{array}$ & Advanced & Native Level \\
\hline & & & & & \\
\hline
\end{tabular}

3. English Proficiency Test Score (e.g. CET-4, College Entry Test Score, IETLS, TOEFL etc.)

4. Please mark the best/primary reason for you to learn business English:

5. Please rate your level of overall motivation to learn English as__ (high/medium/low).

6. Circle the number that best indicates your perception of your language ability in your major with 4 being the highest level of language ability.
a. Listening 4321
b. Speaking 4321
c. Reading 4321
d. Writing 4321

7. What kind of writing do you do in the program study? (4 a lot; 3 sometimes; 2 rarely; 1 never)

a. Essay assignments $\quad 4321$

b. Essay tests 4321

c. Letters 4321

d. Reports 4321

e. Research papers $\quad 4321$

f. Summary of lectures 4321

g. Note-taking in class 4321

h. Note-taking/internet 4321

i. Other: Specify___ 4321

8 . Which business skills would you like to improve?

Speaking

$\square$ Public speaking

$\square$ Describing things when you don't know the exact word

$\square$ Staying on a topic

$\square$ Persuasive questioning

$\square$ Dealing with communication problems

Reading

$\square$ Reports

$\square$ Correspondence

$\square$ Articles, journals, abstracts and trade publication

$\square$ Quick reading for specific information and key points

Writing

$\square$ Reports 


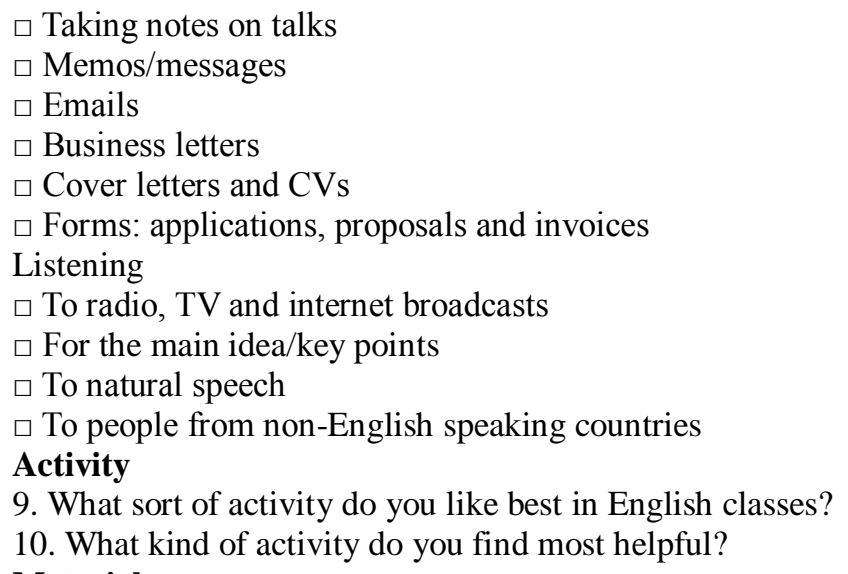

\section{Material}

11. Are there any topics of business English that you wish to learn? Please provide details.

\section{Learning Resources}

12. How do you help yourself to learn business English outside the classroom?

13. How do you locate the resources for learning business English?

\section{ACKNOWLEDGEMENTS}

The author would like to express heartfelt thanks to the participants for their helpful contributions to the study. The author is also grateful for the expert comments from editors and reviewers for revising this article. This work was funded by 9th China Foreign Language Education Research Fund [ZGWYJYJJ2018B14].

\section{REFERENCES}

[1] An, H. (2008). Chong Fen Li Yong Hu Lian Wang Jiao Xue Zi Yuan Cu Jin Da Xue Ying Yu Jiao Xue Gai Ge [Full use of internet resources to facilitate college English teaching reform]. Journal of Shandong Youth Administrative Cadres College, No .5 Sep. No.135, 138-139.

[2] Barkhuizen, G. P. (1998). Discovering Learners' Perceptions of ESL Classroom Teaching/Learning Activities in a South African Context. TESOL Quarterly, Vol. 32, No. 1, 85-108.

[3] Basturkmen, H. (2010). Developing Courses in English for Specific Purposes. Basingstoke, New York: Palgrave Macmillan.

[4] Block, D. (1994). A Day in the Life of a Class: Teacher/Learner Perceptions of Task Purpose in Conflict. System, Vol. 22 No.4: 473-486.

[5] Brown, J.D. (2014). Mixed Methods Research for TESOL. Edinburgh: Edinburgh University Press.

[6] Brumfit, C.J. and Johnson, K. (2000). The Communicative Approach to Language Teaching. Shanghai: Shanghai Foreign Language Education Press.

[7] Cao, Y.R. (2015). Shi Lun Shang Wu Ying Yu Ke Cheng She Zhi yu Jiao Xue She Ji [A study on the business English curriculum and teaching design]. Journal of Language and Literature, 2015 (1):142-144.

[8] Creswell, J. W. (2014). Research Design: Qualitative, Quantitative, and Mixed Methods Approaches. London: Sage Publications Inc.

[9] Davies, R. J. (2015). Why tweet when you can bubble? Students' perceptions of a voice microblog for the development of their L2 spoken production skills. Jaltcall Journal Vol. 11, No.3: 213-233.

[10] Donna, S. (2000). Teach Business English. Cambridge: Cambridge University Press.

[11] Dörnyei, Z. and Taguchi, T. (2011). Questionnaires in Second Language Research: Construction, Administration, and Processing (Second Edition). Beijing: Foreign Language Teaching and Research Press.

[12] Dudley-Evans, T. and St John, M. J. (1998). Developments in English for Specific Purposes. Cambridge: Cambridge University Press.

[13] Edwards, N. (2000). Language for business: effective needs assessment, syllabus design and materials preparation in a practical

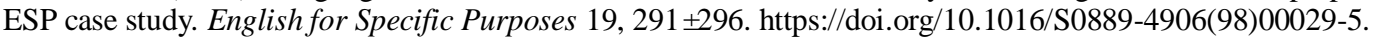

[14] Ellis, M. and Johnson, C. (2002). Teaching Business English. Shanghai: Shanghai Foreign Language Education Press.

[15] Emmerson, P. and Hamilton, N. (2005). Five-Minute Activities for Business English. Cambridge: Cambridge University Press.

[16] Evans, S. (2012). Designing email tasks for the Business English classroom: Implications from a study of Hong Kong's key industries. English for Specific Purposes 31 (2012) 202-212. https://doi.org/10.1016/j.esp.2012.03.001.

[17] Flowerdew, L. (2011). 10 ESP and Corpus Studies. In D. Belcher, A. M. Johns, and B. Paltridge (Eds), New directions in English for specific purposes research (pp.222-245). Ann Arbor, Mich.: University of Michigan Press.

[18] Frendo, E. (2005). How to teach business English. Essex, England: Pearson Education Limited.

[19] Fuertes-Olivera, P. A. and Go' mez-Martı'nez, S. (2004). Empirical assessment of some learning factors affecting Spanish students of business English. English for Specific Purposes 23: 163-180. doi:10.1016/S0889-4906(02)00044-3.

[20] Guest, G., MacQueen, K. M., and Namey, E. E. (2012). Applied Thematic Analysis. Thousand Oaks, Calif.: Sage Publications.

[21] Harding, K. (2007). English for Specific Purposes. Oxford: Oxford University Press.

[22] Hedge, T. (2002). Teaching and Learning in the Language Classroom. Oxford: Oxford University Press

[23] Hou J.X. (2008). Pou Xi Ying Xiang Cheng Ren Ying Yu Xue Xi de Yin Su [Analyzing Factors Influencing Adult English 
Learning Outcomes]. Journal of Shanxi Finance and Economics University (higher education edition). Vol. 11 No. $2,82$.

[24] Hu, Y. P. (2015). Wang Luo Zi Yuan zai Gao Xiao Shang Wu Ying Yu Jiao Xue Zhong de Ying Yong Tan Jiu [An inquiry of the use of internet resources in business English teaching]. Journal of Higher Education, 2015 (12):42-43.

[25] Hutchinson, T. and Waters, A. (1987). English for Specific Purposes: A Learning Centered Approach. Cambridge: Cambridge University Press.

[26] Irigoin, J., and Tsai, B. (1995). Business English Recipes: A Creative Approach to Business English. Essex, England: Longman Group Limited.

[27] Jackson, J. (2003). Case-based learning and reticence in a bilingual context: perceptions of business students in Hong Kong. System 31: 457-469. doi:10.1016/j.system.2003.03.001.

[28] Jones-Macziola, S. and White, G. (2003). Further Ahead: A Communication Skills Course for Business English: Learner's Book. Cambridge: Cambridge University Press.

[29] Liu, J. (2015). Qiao Yong Wang Luo Ke Cheng Zi Yuan Ti Gao Shang Wu Ying Yu Jiao Xue Cheng Xiao [Creative use of internet teaching resources to improve business English effectiveness]. Journal of Higher Education, 2015 (13):57-58.

[30] Lu, C. (2015). Business English Teaching Practice under Network Resources Support. The Guide of Science \& Education, 2015 (4):107-110.

[31] McGrath, I. (2013). Teaching Materials and the Roles of EFL/ESL Teachers: Practice and Theory. London: Bloomsbury.

[32] Mishan, F. (2013). 18 Modes of delivery. In B. Tomlinson (Ed.), Applied Linguistics and Materials Development (pp.287-301). London: Bloomsbury.

[33] Pratoomrat, P. and Rajprasit, K. (2014). Providing Business English Instruction: Thai Instructors' Practices and Students' Perceptions. English Language Teaching, Vol. 7, No. 9, 144-155. DOI:10.5539/elt.v7n9p144.

[34] Richards, J. C. and Rodgers, T. S. (1986). Approaches and Methods in Language Teaching: A Description and Analysis. Cambridge: Cambridge University Press.

[35] Robinson, P. (1991). ESP Today: A Practitioner's Guide. London: Prentice Hall.

[36] Sun, Y. (2017). Business English Vocabulary Teaching Based on Cognitive Engagement and Production-oriented Approach. Foreign Language Research 2017, No. 6, Serial No. 199, 83-89.

[37] Trinder, R. (2013). Business students' beliefs about language learning in a university context. English for Specific Purposes 32: 1-11. http://dx.doi.org/10.1016/j.esp.2012.06.003.

[38] Vallance, M. (1998). The design and use of an internet resource for business English learners. ELT Journal, Volume 52, 1, $38-42$.

[39] Wang, J. H., Zou, B., Wang, D.S., and Xing, M.J. (2013). Students' perception of a wiki platform and the impact of wiki engagement on intercultural communication. System 41: 245-256. http://dx.doi.org/10.1016/j.system.2013.04.004.

[40] Wei, Z. (2004). English Learners' Perceptions of Oral English Classroom Activities. Journal of PLA University of Foreign Languages, Vol. 27 No. 4: 44-48.

[41] Wen, Q.F. (2016). The production-oriented approach to teaching university students English in China. Lang. Teach.: 1-15. https://doi.org/10.1017/S026144481600001X.

[42] Yang, Z.X. (2012). Chinese Companies versus Foreign Companies: A Practical Business English Reader. Beijing: Foreign Language Teaching and Research Press.

[43] Yogman, J. and Kaylani, C. T. (1996). ESP Program Design for Mixed Level Students. English for Specific Purposes, Vol. 15, No. 4, 311-324.

[44] Zhang, W.Y., Perris, K., and Yeung, L. (2005). Online tutorial support in open and distance learning: students' perceptions. British Journal of Educational Technology, Vol 36 No 5:789 - 804. https://doi.org/10.1111/j.1467-8535.2004.00492.x.

Qing Xie was born in Ninghai, China in 1981. She received her PH.D. in Language Education and Technical and Vocational Education and Training from The Education University of Hong Kong, China.

She is currently a lecturer in the School of Foreign Studies, Jiangnan University China. Her research interests include English for specific purposes, corporate training and curriculum development.

Dr. Xie is a member of China Foreign Language Research Association English for Specific Purposes Interest Group. 